\title{
Pengembangan Produk Unggulan Aisyiyah Cabang Moyudan Melalui Kuliner Jepang
}

\author{
The Development of Superior Products by Moyudan's Branch of Aisyiyah Through Japanese \\ Culinary
}

\author{
${ }^{1 *}$ Azizia Freda Savana, ${ }^{2)}$ Wistri Meisa, ${ }^{3)}$ Arda Putri Winata \\ ${ }^{1,2)}$ Pendidikan Bahasa Jepang, Fakultas Pendidikan Bahasa, ${ }^{3)}$ Perpustakaan \\ Universitas Muhammadiyah Yogyakarta \\ Jl. Brawijaya, Tamantirto, Bantul, Yogyakarta \\ *email: aziziafreda@umy.ac.id
}

DOI:

\begin{abstract}
ABSTRAK dalam kegiatan peningkatan kesejahteraan masyarakat. Untuk meningkatkan dan mengembangkan ekonomi umat, majelis ekonomi Pengurus Cabang Aisyiyah (PCA) Moyudan mempunyai permasalahan, yaitu kurang adanya pengembangan produk unggulan untuk meningkatkan pendapatan saat melakukan kegiatan bazar atau pameran guna meningkatkan ekonomi umat. PCA Moyudan mengharapkan adanya produk makanan yang menjadi ciri khas cabang tersebut untuk menarik pengunjung atau masyarakat. Berdasarkan permasalahan tersebut, Program studi Pendidikan Bahasa Jepang, Universitas Muhammadiyah Yogyakarta (UMY) menawarkan pelatihan kuliner Jepang untuk pengembangan produk unggulan Aisyiyah Cabang Moyudan dan pengemasan ramah lingkungan. Kegiatan ini menggunakan metode ceramah dan praktik berupa pelatihan memasak okonomiyaki untuk ibu-ibu majelis ekonomi PCA Moyudan. Selain itu, dalam pelatihan ini juga disosialisasikan tentang dampak penggunaan plastik terhadap lingkungan. Tujuan pengabdian masyarakat ini adalah membantu produk makanan unggulan Asyiyah cabang Moyudan dengan menawarkan makanan Jepang yaitu, okonomiyaki. Hasil dari pelatihan ini adalah terciptanya produk unggulan baru yang bisa dikembangkan oleh PCA Moyudan untuk meningkatkan pendapatan. Pelatihan ini tidak hanya menghasilkan produk saja, tetapi diharapkan keberlanjutan pemasaran produk dengan bahan ramah lingkungan.
\end{abstract}

10.30595/jppm.v5i1.9709 Aisyiyah cabang Moyudan merupakan salah satu cabang Aisyiyah yang aktif

Kata kunci: Makanan Ringan Jepang; Okonomiyaki; Produk Unggulan

\begin{abstract}
The Moyudan's branch of Aisyiyah is one of Aisyiyah's branches that is quite active in improving community welfare. To improve and develop the people's economy, the economic council of Moyudan's Aisyiyah Branch Manager (ABM) has a problem, namely the lack of superior products' development to increase income when conducting bazaars or exhibitions to improve the people's economy. Moyudan's ABM hopes that there are food products that characterize the branch to attract visitors or the public. Based on this problem, the Japanese Language Education Department, Universitas Muhammadiyah Yogyakarta, offers Japanese culinary training to develop superior products of Aisyiyah in Moyudan, and eco-friendly packaging. This activity used lecture and practical methods in okonomiyaki cooking training for the Moyudan's ABM economic council members. Also, this training socializes the impact of using plastic on the environment. This community service aims to help the Aisyiyah superior food product in Moyudan offering Japanese food, named okonomiyaki. The result of this training is the creation of new superior products that Moyudan's ABM could develop to increase the income. This training does not only produce products, but it is also hoped that the product marketing with eco-friendly materials could be continued.
\end{abstract}




\section{PENDAHULUAN}

Aisyiyah mempunyai amal usaha yang bergerak di berbagai bidang, yaitu bidang kesehatan, kesejahteraan sosial, ekonomi, dan pemberdayaan masyarakat. Aisyiyah mempunyai beberapa majelis dan lembaga, salah satunya adalah majelis ekonomi. Aisyiyah berpendapat bahwa harkat dan martabat perempuan Indonesia tidak akan meningkat tanpa peningkatan kemampuan ekonominya. Oleh karena itu, Aisyiyah mempunyai program pemberdayaan ekonomi dengan visi "tertatanya kemampuan organisasi dan jaringan aktivitas pemberdayaan ekonomi keluarga untuk meningkatkan kesejahteraan masyarakat". Majelis ekonomi Aisyiyah bergerak memberdayakan ekonomi rakyat kecil dan menengah serta mengembangkan ekonomi kerakyatan. Beberapa program majelis ekonomi adalah Mengembangkan Bina Usaha Ekonomi Keluarga Aisyiyah (BUEKA), Usaha Mikro Kecil Menengah (UMKM), menumbuhkan dan mengembangkan koperasi serta lembaga keuangan mikro yang berbadan hukum, meningkatkan partisipasi Aisyiyah dalam pembelaan dan penguatan termasuk advokasi terhadap tenaga kerja indonesia khususnya tenaga kerja wanita, membangun jaringan dengan berbagai pihak dalam rangka mengembangkan ekonomi umat, melakukan advokasi dan perlindungan konsumen, dll. (Muhammadiyah, 2011).

Majelis ekonomi dari berbagai cabang Aisyiyah juga melakukan hal yang sama dalam meningkatkan pemberdayaan ekonomi. Setiap cabang mempunyai strategi tersendiri untuk mewujudkan kegiatan yang berguna bagi kesejahteraan masyarakat. Untuk mendukung terwujudnya kegiatan tersebut, setiap majelis dalam cabang Aisyiyah saling berkesinambungan dan mencari pendapatan dengan menyelenggarakan kegiatan bazar atau menghadiri pameran dalam setiap event, baik di Muhammadiyah maupun luar. Selain untuk mencari pendapatan cabang Asyiyah, hal ini dilakukan untuk meningkatkan dan mengembangkan ekonomi umat. Salah satu cabang Aisyiyah yang aktif dalam kegiatan peningkatan kesejahteraan masyarakat adalah Aisyiyah cabang Moyudan.

Aisyiyah cabang Moyudan diketuai oleh Dra. Hj. Suharti dan mempunyai anggota kurang lebih 25 orang yang aktif dalam mengikuti pengajian dan berbagai kegiatan lain. Berdasarkan wawancara yang telah dilakukan, Aisyiyah cabang Moyudan sering melakukan bazar pada waktu pengajian ataupun acara bazar yang bekerja sama dengan cabang Aisyiyah lainnya. Tidak hanya itu, mereka juga aktif mengikuti pameran dalam acara yang diselenggarakan oleh pusat Muhammadiyah dan Aisiyah. Biasanya, produk yang diminati oleh masyarakat adalah makanan. Karena dirasa produk makanan yang dimiliki dan dijual oleh Aisyiyah cabang Moyudan tergolong biasa saja dan kebanyakan produk makanan yang dijual sama dengan cabang Aisyiyah lainnya, mereka ingin mengembangkan suatu produk unggulan makanan sebagai ciri khas produk makanan yang dimiliki oleh Aisyiyah cabang Moyudan.

Menurut Humaizah dan Mabruroh (2008), produk unggulan adalah produk yang potensial untuk dikembangkan dengan mengembangkan sumber daya setempat, serta mendatangkan pendapatan bagi masyarakat dan pemerintah. Produk unggulan juga merupakan produk yang memiliki daya saing, berorientasi pasar, dan ramah lingkungan sehingga tercipta keunggulan yang kompetitif yang siap menghadapi persaingan global (Didi Sudiana dalam Kurniawan, 2017). Menurut Ibu Sri Ayem, koordinator majelis ekonomi, penjualan produk makanan yang dijual hampir sama dengan cabang lain sehingga sulit untuk meningkatkan pendapatan secara signifikan. Hal tersebut kurang membangkitkan selera masyarakat untuk membeli produk yang telah ditawarkan. Oleh karena itu, apabila Aisyiyah cabang Moyudan mempunyai produk makanan yang tidak dimiliki oleh cabang lain, kemungkinan masyarakat akan lebih tertarik sehingga akan meningkatkan pemasukan Aisyiyah cabang Moyudan.

Pemaparan tersebut merupakan permasalahan yang dihadapi oleh Aisyiyah 
cabang Moyudan dalam meningkatkan pendapatan serta pemberdayaan ekonomi yang produktif untuk anggota maupun masyarakat. Melalui program pengabdian ini, tim pelaksana menawarkan solusi untuk mengembangkan produk makanan yang berbeda sebagai produk unggulan, yaitu makanan Jepang berupa okonomiyaki yang dikemas dengan bahan ramah lingkungan. Okonomiyaki sudah dikenal di Indonesia dan menjadi salah satu makanan favorit selain takoyaki.

Okonomiyaki adalah salah satu makanan ringan yang populer di seluruh Jepang, khususnya wilayah kansai (Cahyana, 2020). Okonomiyaki berisi gurita, cumi-cumi, udang, sayuran (biasanya kol). Adonan Okonomiyaki terbuat dari telur, tepung terigu, air, dashi, nagaimo (Press.ikidane-nippon.com, 2018) Okonomiyaki disajikan dalam bentuk bulat atau kotak dan ditaburi dengan katsuobushi, mayones, dan aonori. Bentuk, isi, dan topping bisa disesuaikan dengan selera masing-masing atau sesuka orang yang membuat. Hal ini sesuai dengan arti dari okonomiyaki, okonomi artinya suka-suka atau yang disuka dan yaki artinya panggang atau bakar. Harga satu okonomiyaki di Jepang adalah 600 - 1.500 Yen ( \pm Rp. 80.000,00 - Rp.175.000,00) tergantung kualitas bahan dan isinya (JNTO).

\section{METODE}

Kegiatan pengabdian kepada masyarakat (PKM) ini menggunakan pendekatan persuasif edukatif dengan metode ceramah dan praktik memasak okonomiyaki untuk ibu-ibu Aisyiyah cabang Moyudan yang berupa pelatihan. Tujuan diadakan pelatihan ini adalah membekali Majelis Ekonomi PCA Moyudan cara memasak makanan Jepang yaitu okonomiyaki sesuai dengan hasil observasi yang telah dilakukan dan pengemasan yang ramah lingkungan. Sesuai dengan permasalahan yang dihadapi oleh mitra, pelaksanaan program ini dilakukan dalam tahap persiapan dan tahap pelaksanaan yang terdiri atas dua kali kegiatan.

1. Tahap Persiapan

a. Observasi

Tim pelaksana melakukan identifikasi masalah melalui FGD dengan ketua
Aisyiyah cabang Moyudan dan koordinator majelis ekonomi.

b. Menyiapkan Alat dan Bahan

Setelah melakukan observasi dan menemukan masalah terkait pelaksanaan program, tim pelaksana menyusun daftar alat dan bahan yang diperlukan untuk pelatihan dan praktik membuat makanan okonomiyaki.

c. Menguji Resep Okonomiyaki

Resep yang akan digunakan dalam pelatihan sebelumnya melalui proses uji coba terlebih dahulu. Terdapat dua resep yang diujicobakan, yaitu resep original yang menggunakan bahan premium berupa tepung okonomiyaki premiks dan resep modifikasi yang menggunakan bahan substitusi dari produk lokal. Kedua resep dibandingkan dan kemudian dibuat varian isi menjadi okonomiyaki original dan okonomiyaki varian. Dari hasil uji coba, resep kemudian dicetak dalam bentuk booklet dan dibagikan pada saat pelaksanaan kegiatan.

d. Merancang Desain Label dan Kemasan Produk

Tim pelaksana mempersiapkan pengemasan produk dan desain label. Desain dibuat yang menarik dan mewakili keunggulan serta ciri khas produk.

\section{Tahap Pelaksanaan}

a. Kegiatan Hari Pertama

Kegiatan pada hari pertama terdapat dua sesi. Sesi pertama adalah sosialisasi makanan Jepang yang berupa okonomiyaki kepada anggota Aisyiyah cabang Moyudan. Sesi kedua adalah pemberian materi pembuatan okonomiyaki original dan pelaksanaan demonstrasi pembuatan okonomiyaki original.

b. Kegiatan Hari Kedua

Kegiatan hari kedua terdapat dua sesi. Sesi pertama adalah pemberian materi pembuatan okonomiyaki rasa varian dengan style yang berbeda dan pelaksanaan demonstrasi pembuatan okonomiyaki rasa varian. Sesi kedua 
adalah pendampingan pengemasan produk.

\section{HASIL DAN PEMBAHASAN}

Kegiatan pengabdian kepada masyarakat ini dibagi menjadi tiga kegiatan, yaitu prapelaksanaan, pelaksanaan, dan keberlanjutan program.

1. Pra-pelaksanaan atau Persiapan

a. Observasi

Tim pelaksana program melakukan Forum Group Discussion (FGD) sebelum pelaksanaan kegiatan. Hal ini berujuan mengidentifikasi masalah yang ada di Aisyiyah cabang Moyudan, khususnya yang berhubungan dengan majelis ekonomi untuk pengembangan produk unggulan. Berikut adalah hasil FGD dan tindak lanjut masalah.

1) Hasil FGD

a) Produk makanan yang dihasilkan sama dengan produk dari cabang lainnya sehingga tidak mempunyai ciri khas produk tersendiri.

b) Aisyiyah cabang Moyudan belum memiliki peralatan memadai untuk membuat penganan Okonomiyaki.

2) Tindak Lanjut Masalah

a) Memperkenalkan panganan okonomiyaki dalam bentuk sosialisasi budaya dan kuliner Jepang.

b) Menghibahkan peralatan seperti teflon, kompor, serta alat masak yang digunakan dalam pelatihan.

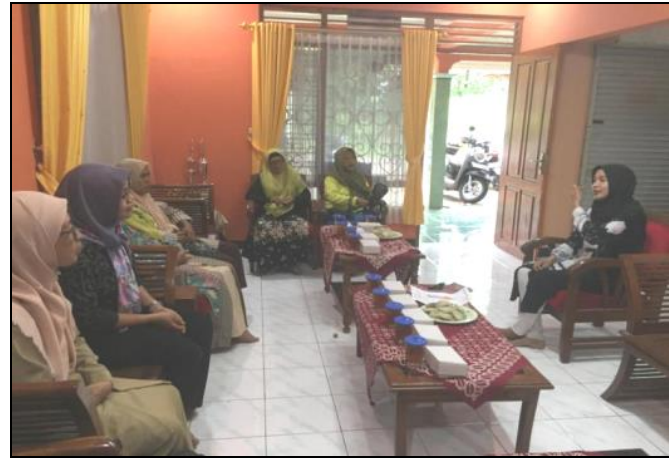

Gambar 1. Forum Group Discussion

b. Menyiapkan Alat dan Bahan

Setelah melakukan observasi dan menemukan masalah terkait pelaksanaan program, tim pelaksana menyusun daftar barang yang diperlukan untuk tindak lanjut masalah dan pelaksanaan program. Persiapan yang dilakukan sebagai berikut.

1) Membeli wajan teflon untuk menggoreng adonan.

2) Membeli kompor portabel untuk memasak okonomiyki.

3) Membeli peralatan masak lainnya seperti talenan, spatula, dan sebagainya.

4) Membeli bahan masakan seperti minyak goreng, tepung premix original, tepung terigu lokal, saus okonomiyaki, bahan saus lokal, katsuobushi, dan sebagainya.

c. Menguji Resep Okonomiyaki

Resep yang akan digunakan dalam pelatihan sebelumnya melalui proses uji coba terlebih dahulu. Terdapat dua resep yang diujicobakan, yaitu resep original dan resep varian. Resep original menggunakan bahan premium berupa tepung premiks dengan isian gurita dan sayuran. Resep varian menggunakan bahan dari produk lokal dengan isian keju, sosis, dan sayuran. Berdasarkan hasil uji coba, resep kemudian dicetak dalam bentuk booklet resep dan kemudian dibagikan saat sosialisasi kuliner Jepang kepada anggota pelatihan, 
yaitu kelompok majelis ekonomi Aisyiyah PCA Moyudan.

d. Merancang Desain Label dan Kemasan Produk

Sebelum pelatihan dilaksanakan, tim pelaksana juga mempersiapkan kemasan produk dan desain label. Desain dirancang sesuai dengan produk yang akan ditawarkan dan dapat mewakili keunggulan serta ciri khas produk. Label produk dalam kemasan okonomiyaki PCA Moyudan dapat dilihat pada gambar berikut.

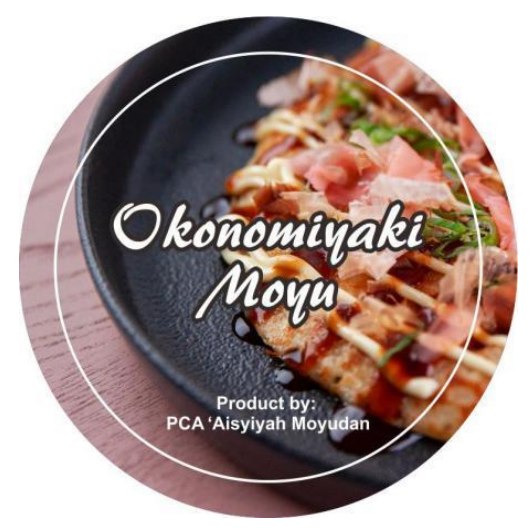

Gambar 2. Label Kemasan Okonomiyaki PCA Moyuda
Tabel 1. Hasil dan capaian kegiatan prapelaksanaan

\begin{tabular}{|c|c|c|c|}
\hline $\begin{array}{l}\text { Tahapan } \\
\text { Kegiatan }\end{array}$ & Tujuan & Sasaran & Hasil \\
\hline Observasi & $\begin{array}{l}\text { Mengetahui } \\
\text { permasalah } \\
\text { an dan hal- } \\
\text { hal atau } \\
\text { rancangan } \\
\text { program } \\
\text { yang harus } \\
\text { dipersiapka } \\
\text { n sebelum } \\
\text { pelaksanaan }\end{array}$ & $\begin{array}{l}\text { Majelis } \\
\text { Ekonomi } \\
\text { Aisyiyah } \\
\text { cabang } \\
\text { Moyudan }\end{array}$ & $\begin{array}{l}\text { Mengetaui } \\
\text { permasalaha } \\
\mathrm{n} \text { dan } \\
\text { menawarkan } \\
\text { solusi untuk } \\
\text { membuat } \\
\text { produk } \\
\text { makanan } \\
\text { Jepang. }\end{array}$ \\
\hline $\begin{array}{l}\text { Menyiap } \\
\text { kan Alat } \\
\text { dan } \\
\text { Bahan }\end{array}$ & $\begin{array}{l}\text { Sebagai alat } \\
\text { penunjang } \\
\text { kegiatan } \\
\text { praktik } \\
\text { memasak } \\
\text { okonomiyak } \\
\text { i. }\end{array}$ & Tim PPM & $\begin{array}{l}\text { Pengadaan } \\
\text { peralatan } \\
\text { penunjang } \\
\text { (teflon, } \\
\text { kompor } \\
\text { portabel, dan } \\
\text { perlengkapa } \\
\text { n memasak } \\
\text { lainnya) }\end{array}$ \\
\hline $\begin{array}{l}\text { Melakuk } \\
\text { an Uji } \\
\text { Coba } \\
\text { Resep } \\
\text { Okonomi } \\
\text { yaki }\end{array}$ & $\begin{array}{l}\text { Mencoba } \\
\text { resep yang } \\
\text { akan } \\
\text { dipraktikka } \\
\text { n oleh mitra } \\
\text { dengan } \\
\text { resep } \\
\text { original dan } \\
\text { resep } \\
\text { produk } \\
\text { lokal. }\end{array}$ & Tim PPM & $\begin{array}{l}\text { Terdapat dua } \\
\text { jenis resep } \\
\text { okonomiyaki } \\
\text { berupa } \\
\text { okonomiyaki } \\
\text { original dan } \\
\text { okonomiyaki } \\
\text { varian sosis } \\
\text { keju. }\end{array}$ \\
\hline $\begin{array}{l}\text { Merancan } \\
\text { g Desain } \\
\text { Label dan } \\
\text { Kemasan } \\
\text { Produk }\end{array}$ & $\begin{array}{l}\text { Desain } \\
\text { label untuk } \\
\text { digunakan } \\
\text { pada saat } \\
\text { pemasaran } \\
\text { agar ke } \\
\text { depannya } \\
\text { mempunyai } \\
\text { merek } \\
\text { dagang dan } \\
\text { kemasan } \\
\text { produk } \\
\text { ramah } \\
\text { lingkungan }\end{array}$ & $\begin{array}{l}\text { Aisyiyah } \\
\text { Cabang } \\
\text { Moyudan }\end{array}$ & $\begin{array}{l}\text { Produk } \\
\text { dikemas } \\
\text { dalam } \\
\text { tempat } \\
\text { ramah } \\
\text { lingkungan, } \\
\text { yaitu kardus } \\
\text { dan dilabeli } \\
\text { stiker } \\
\text { dengan } \\
\text { desain dan } \\
\text { merek } \\
\text { dagang } \\
\text { Aisyiyah } \\
\text { PCA } \\
\text { Moyudan. }\end{array}$ \\
\hline
\end{tabular}


2. Pelaksanaan

Pelaksanaan dilakukan pada masa pandemi dengan menerapkan protokol kesehatan. Tahap ini terdiri atas dua kali kegiatan yaitu, kegiatan hari pertama dan kedua.

a. Kegiatan Hari Pertama

Pada sesi pertama, kegiatan diawali dengan sosialisasi mengenai kuliner Jepang kepada kelompok majelis ekonomi PCA Moyudan. Sesi kedua adalah pemberian materi pembuatan okonomiyaki dan pelaksanaan demonstrasi memasak berupa pembuatan okonomiyaki dengan resep original yang menggunakan bahan premix original (cookpad.com, 2014). Selanjutnya, kelompok praktik memasak dibagi menjadi 4 kelompok.

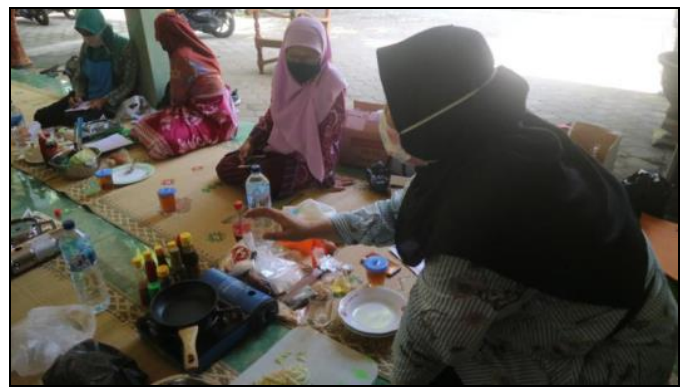

Gambar 3. Sosialisi Mengenai Kuliner Jepang

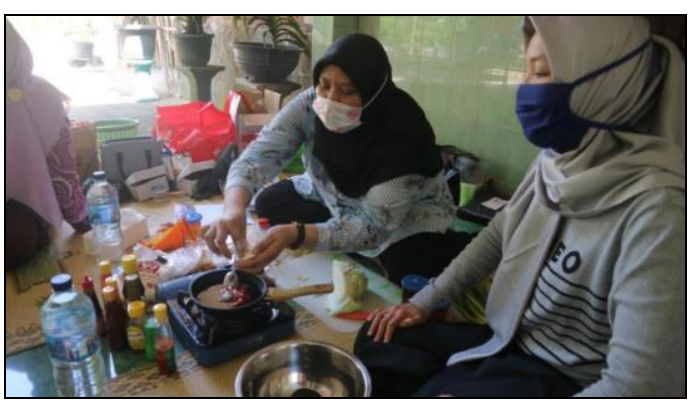

Gambar 4. Demo Pembuatan Okonomiyaki

b. Kegiatan Hari Kedua

Sesi pertama adalah pemberian materi pembuatan okonomiyaki dan pelaksanaan demonstrasi memasak berupa pembuatan okonomiyaki dengan resep rasa varian yang menggunakan bahan bahan tepung biasa dan mempraktikkannya. Sesi kedua adalah sosialisasi pengemasan ramah lingkungan dengan tidak menggunakan plastik dalam pengemasan produk.

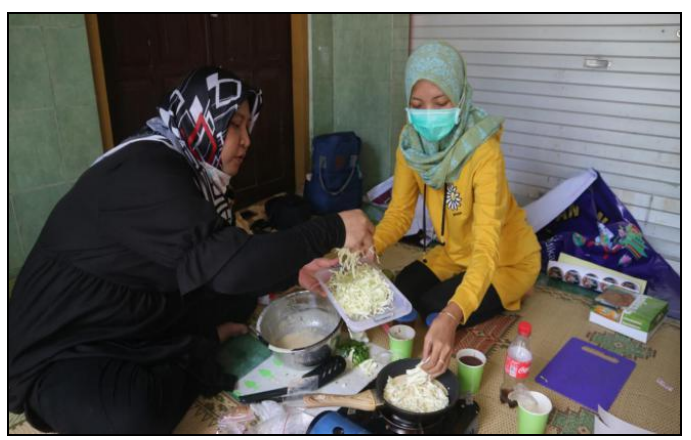

Gambar 5. Demo dan Praktik Pembuatan Okonomiyaki Rasa Varian

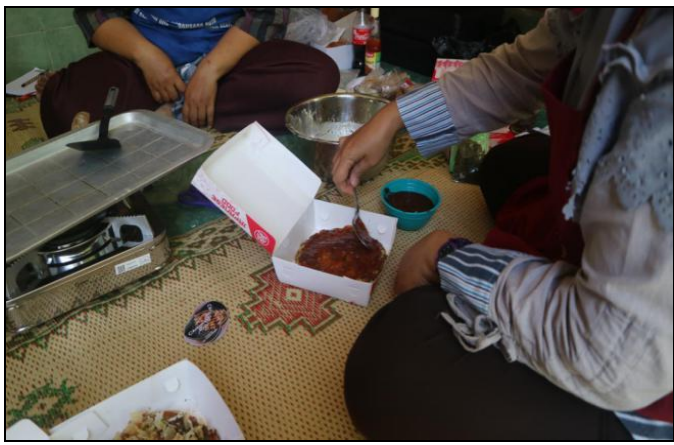

Gambar 6. Pengemasan Produk

Pelaksanaan program pelatihan memasak okonomiyaki dilakukan dalam beberapa kegiatan yang dikemas dalam dua pertemuan kegiatan. 
Tabel 2. Hasil dan capaian tahap pelaksaaan

\begin{tabular}{|c|c|}
\hline $\begin{array}{l}\text { Tahapan } \\
\text { Kegiatan }\end{array}$ & Hasil \\
\hline $\begin{array}{l}\text { Sosialisasi } \\
\text { kepada } \\
\text { Kelompok } \\
\text { Majelis } \\
\text { Ekonomi PCA } \\
\text { Moyudan } \\
\text { tentang } \\
\text { Produk } \\
\text { Makanan } \\
\text { Jepang. }\end{array}$ & $\begin{array}{l}\text { Kelompok Majelis Ekonomi } \\
\text { PCA Moyudan menyambut } \\
\text { baik pengembangan produk } \\
\text { makanan kuliner berupa } \\
\text { okonomiyaki dan mempunyai } \\
\text { pandangan baru bahwa } \\
\text { produk tersebut mempunyai } \\
\text { prospek yang baik sebagai } \\
\text { ciri khas produk makanan } \\
\text { yang dapat dikembangkan } \\
\text { untuk meningkatkan } \\
\text { perekonomian cabang. }\end{array}$ \\
\hline $\begin{array}{l}\text { Demonstrasi } \\
\text { \& Praktik } \\
\text { Memasak } \\
\text { Okonomiyaki } \\
\text { Original }\end{array}$ & $\begin{array}{l}\text { Kelompok Majelis Ekonomi } \\
\text { PCA Moyudan dapat } \\
\text { membuat okonomiyaki } \\
\text { dengan varian original } \\
\text { dengan baik. }\end{array}$ \\
\hline $\begin{array}{l}\text { Demonstrasi } \\
\text { \& Praktik } \\
\text { Memasak } \\
\text { Okonomiyaki } \\
\text { Varian Sosis } \\
\text { Keju }\end{array}$ & $\begin{array}{l}\text { Kelompok Majelis Ekonomi } \\
\text { PCA Moyudan dapat } \\
\text { membuat okonomiyaki varian } \\
\text { isi sosis keju dengan baik. }\end{array}$ \\
\hline $\begin{array}{l}\text { Pendampingan } \\
\text { Penge-masan } \\
\text { Produk } \\
\text { dengan Bahan } \\
\text { Ramah } \\
\text { Lingkungan. }\end{array}$ & $\begin{array}{l}\text { Kelompok majelis ekonomi } \\
\text { PCA Moyudan mendapat } \\
\text { pengetahuan dengan } \\
\text { pengemasan tanpa plastik dan } \\
\text { dapat mengemas produk serta } \\
\text { melabeli dengan merek } \\
\text { dagang yang telah disepakati }\end{array}$ \\
\hline $\begin{array}{l}\text { Penyediaan } \\
\text { Perlengkapan } \\
\text { Memasak } \\
\text { Okonomiyaki }\end{array}$ & $\begin{array}{l}\text { Alat memasak berupa teflon } \\
\text { seukuran okonomiyaki, } \\
\text { kompor portabel, dan } \\
\text { perlengkapan memasak } \\
\text { lainnya dikelola oleh } \\
\text { Pengurus Majelis Ekonomi } \\
\text { PCA Moyudan. }\end{array}$ \\
\hline
\end{tabular}

3. Keberlanjutan Program

Keberlanjutan program terdiri atas terciptanya produk unggulan sebagai unit usaha Aisyiyah cabang Moyudan dan pemasaran produk. Ibu-ibu Aisyiyah Majelis Ekonomi PCA Moyudan berhasil mempraktikkan dan memasak okonomiyaki dengan rasa original dan rasa varian.
Majelis ekonomi PCA Moyudan membutuhkan peralatan untuk membuat dan menghasilkan okonomiyaki sebagai produk ekonomi kreatif yang akan dikembangkan. Oleh karena itu, alat memasak okonomiyaki berupa teflon, kompor portabel, dan perlengkapan memasak lainnya diberikan dan dikelola oleh Pengurus Majelis Ekonomi PCA Moyudan.

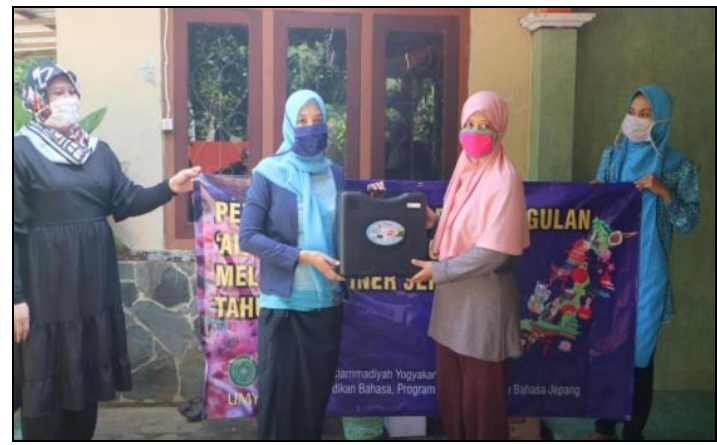

Gambar 7. Penyerahan Peralatan Memasak Okonomiyaki

Pelaksanaan seluruh rangkaian program dapat terlihat dari beberapa indikator keberhasilan. Pertama, Majelis Ekonomi PCA Moyudan kini mempunyai pandangan baru tentang produk makanan yang akan dikembangkan menjadi produk unggulan Aisyiyah cabang Moyudan. Kedua, hal ini juga memotivasi anggota kelompok untuk merintis unit usaha individu sebagai alternatif dalam meningkatkan perekonomian. Ke depannya, dengan pendampingan yang intensif, diharapkan Majelis Ekonomi PCA Moyudan mampu melakukan pemasaran dan menjadikan produk ini menjadi produk unggulan cabang.

\section{SIMPULAN}

Program pemberdayaan masyarakat melalui pelatihan pembuatan okonomiyaki pada Majelis Ekonomi PCA Moyudan DIY ini dapat memberikan alternatif pemecahan masalah yang terjadi yaitu, Aisyiyah cabang Moyudan mempunyai pandangan baru tentang produk makanan yang akan dikembangkan menjadi produk unggulan Aisyiyah cabang Moyudan. Selain itu juga dapat memotivasi anggota kelompok untuk merintis usaha individu sebagai alternatif dalam meningkatkan perekonomian dengan 
menggunakan resep berbahan dasar produk lokal, dan memiliki merek dagang okonomiyaki yaitu "Okonomiyaki Moyu" yang dapat dimajukan bersama-sama oleh Majelis Ekonomi PCA Moyudan.

\section{DAFTAR PUSTAKA}

Cahyana, L. (2020, April 16). Okonomiyaki, Kuliner Khas Hiroshima Yang Digandrungi Warga. Tempo.Co. Retrieved from https://travel.tempo.co/read/1332054/oko nomiyaki-kuliner-khas-hiroshima-yangdigandrungi-warga, tanggal 29 Januari 2021

Chumaizah \& Mabruroh. (2008). Identifikasi Produk Unggulan Berbasis Ekonomi Lokal Untuk Meningkatkan Pad Di Era Otda. 28-36. Retrieved from http://repository.akprind.ac.id/sites/files/c onferencepaper/2008/mabruroh_21200.pdf

Komugi Ko To Hondashi No Okonomiyaki. (2010). Retrieved January 30, 2021, from Cookpad.com website: https://cookpad.com/recipe/2581094

Kurniawan, H. (2017). Produk Unggulan Lokal Bisa Ikut Bersaing. Merdeka.Com. Retrieved from https://www.merdeka.com/uang/produkunggulan-lokal-bisa-ikut-kembangkanekonomi-daerah.html, tanggal 22 oktober 2020

Okonomiyaki. (n.d.). Retrieved from JNTO website:

https://www.japan.travel/en/ph/guide/oko nomiyaki-takoyaki/tanggal 24 Desember 2019

Perbedaan Antara Okonomiyaki dan Hiroshimayaki. (2018). Retrieved January 29, 2021, from Ikidane Nippon website: https://press.ikidanenippon.com/id/a00243, tanggal 29 Januari 2021

Sejarah Aisyiyah. (n.d.). Retrieved from http://www.muhammadiyah.or.id/id/cont ent-199-det-aisyiyah.html, tanggal 26 Desember 2019 